\title{
Relevance on Islamic Principle Law with Application at the Field: Review of Islamic Banking Publication in Indonesia
}

\author{
Prasetyono Hendriarto \\ Universitas Pakuan, Indonesia \\ Corresponding author email: mas.pras@coret.page
}

\begin{abstract}
This paper evaluates the principles, relevance, and usefulness of Islamic banking law in implementing Islamic banks' administrative systems. Islamic sharia law has become a source of law in several Islamic countries. Sharia law comes from the Islamic religion, which must be applied in many sectors, including the banking system. The goal is to improve kaffah Islamic teachings in aspects of life by adhering to the Koran, a concept to be applied to many systems. Although this banking system has become a fundamental law, studies are still needed to determine the relevance, principles, and application of Islamic banking law with application in the field to see the advantages and disadvantages. An in-depth data analysis process was carried out, which included data coding, critical interpretation, and evaluation that matched the findings with the discussion topic and determined the findings' validity and reliability. Based on the literature, the findings of this study confirm that Islamic banking law has been applied correctly in the context of administrative services in the field because of the effectiveness and vision of the ummah in the context of concepts, principles, and field application; assisting public financial services in Islamic countries.

Keywords---bank administration, islamic banking, journal publication, sharia principle.
\end{abstract}

\section{Introduction}

Muslims' great aspiration in this country to manage their finances using the sharia system has slowly become a reality. Milestones for the establishment and enforcement of Islamic sharia banks such as the Muamalat Indonesia bank have been initiated by Islamic leaders from the MUI and ICMI elements since the new order period was started by teaming up with conventional banks in Indonesia (Utama, 2018; Hardini \& Giharto, 2007; Deti, 2015). In his study of the initial development of Islamic banking law side by side with national banking law in Indonesia. The back and forth of Islamic financial institutions in the country cannot be separated from the principles of sharia rules and practice in the field. Because the driving factor for the advancement of Islamic banks, which is now a significant threat to the continuity of conventional banks, is closely related to internal factors, namely the operational system by the banking itself and external factors, namely recognition by state law and the response of the Muslim community itself. Internal factors such as self-regulation issues of Islamic banks such as Law No. 21/2008 concerning the Sharia banking operational system and the Value Added Taxation Law (VAT) (Eid \& Asutay, 2019; Abu-Tapanjeh, 2009; Olson \& Zoubi, 2008).

The presence of Islamic banks that work dependent on the standards and ideas of Islamic law or sharia has brought the tones and subtleties of the financial framework following the desires of most Muslims in the country. Bank Muamalat Indonesia's activity depends on Law no. 7 of 1992 concerning Banking, and this Act was then corrected by Law no. 10 of 1998. In 2008, Law no. 21 of 2008 concerning Islamic Banking was upheld (Fauzia, 2014; Auda, 2008; Majid, 2012), in her comprehension of the standards basic the financial framework in Islam with a maqashid point of view. al-Sharia. The execution of the standards of sharia is the thing that has a major effect on non-Islamic banks. The standards of sharia allude to Islamic sharia, which is essentially guided by the sacred book of al-Quran and Hadith since Islam is a religion that has an idea that manages human existence in a manner firm and general both concerning God, Habluminallah, and in relations with individual networks, in particular 
Hablumminannas (Arfaizar, 2020; Hessini, 2007; Shibani \& De Fuentes, 2017). Based on this principle applied by Islamic Islamic banks to get a good reception by most Indonesian educated Muslims.

Responding to the 20 years of Islamic banking in Indonesia, the government reported that during the Covid-19 pandemic, the growth of Islamic banking in Indonesia was better than conventional banking (Yudhira, 2021; Putra et al., 2020). This positive growth refers to several parameters based on Indonesian Islamic banking's performance report, which record stable growth. The higher growth of Islamic banks than conventional banks should be appreciated by recording an annual increase of 10.97 percent. Meanwhile, conventional banks increased by 7.7 percent (Tripuspitorini \& Setiawan, 2020; Othman, 2006; Zohdi, 2017; Putrayasa, 2017). Other sources from the government have also influenced branding to increase public knowledge about the economy and Islamic finance that is being developed. Likewise, the inauguration of the 2021 Sharia Economic Brand by President Joko Widodo recently has contributed to the belief of the Muslim community to participate in strengthening the Islamic economic brand supported by a massive increase in literacy, education, and socialization of Islamic economics and finance (Supriyono \& Khalifaturofi'ah, 2021).

When taking a gander at the essential standards of law in Islamic banks, this bank more likely than not got acknowledgment or proof of a unique investigation in the field, for instance, if managerial administrations follow the fundamental standards. Maradita (2014) said that the attributes of Good Corporate Governance in Islamic Banks and Conventional Banks have been working out positively. Is it the execution of sharia rules that is the principle differentiator from customary banks? Fundamentally, these sharia standards allude to Islamic sharia, which the Al Quran and Hadith manage. These principles and concepts need to be opened so that the third party can understand the readiness of Islamic Islamic banks in the field. For example, have Islamic banks operate on the track. Each fatwa from Islamic economic scholars has become a reference for legal products and field applications based on the MUI DSN's collective ijtihad and even the international fatwa authority (Abdad, 2019).

This kind of study is essential to understand any shortcomings that are common in other fields so that it can be anticipated and monitored for improvement so that Islamic banks must comply with sharia laws and regulations. Because the goodness fought for by Islamic sharia law becomes the practice of jahiriyah, namely spreading goodness in the path of Islamic financial development. All of that is not without the foundation and foundation of the ideals of Islamic sharia itself, which include: First, in general, the concept of Islamic bank products is based on the fatwas of the ulama who entered the Indonesian Ulama Council, which was issued after a long study in a focus group discussion conducted by MUI in the aspects of sharia and aspects of sharia accounting, regulators, practitioners, and the Supreme Court of the Republic of Indonesia. So through this collective ijtihad, it is hoped that each fatwa will be correct and avoid mistakes. So that this ijtihad does not slip up in the field when the implementation of Islamic banks carries out the application, we are involved in collecting evidence from field practice. This is in line with Wahid (2016) in his paper, saying that the DSN-MUI Islamic economic fatwa pattern in regulations will strengthen the smooth implementation of Islamic banking in Indonesia.

Second, so that Islamic banks are not groping and misdirected, fatwas must have both the fatwa of Indonesian scholars and international scholars. Furthermore, based on the collective ijtihad of international fatwa authorities such as the AAOIFI International Sharia Standards in Bahrain, the OIC Jurisprudence Institute in Jeddah, and the Islamic Natural Rabithah Fiqh Institute in Makkah, which are references to fatwa authorities in the world. Azhar (2020) said that it is necessary for collective ijtihad between the fuqaha and experts in various sectors of Islamic life. Because through this world scholarly institution that will gather mиamalah experts, such as Sheikh Nidzam Yaqub (Bahrain), Sheikh Abdu Sattar Abu Gudah (Saudi), Sheikh Abdurrahman Athram (Saudi), Sheikh Ali al-Gari (Saudi), Sheikh Husein Hamid Hasan (Egypt), and many other international scholars. They are all scholars who always provide input in the form of fatwas on the legal basis of Islamic banking (Antonio, 2001).

Finally, according to Amin (2017) Islamic legal solutions (Maharaj fiqhiyyah) are driving a new flow of sharia economy in Indonesia: the contribution of the DSN-MUI fatwa in the Indonesian Legislative Regulations. In general, the DSN MUI ijtihad method is the same as the International Fatwa Institute ijtihad this is as outlined by ushul expert scholars, by ensuring that each fatwa has a foundation, whether the Koran, hadith, ijma, urf tujjar, maslahat by examining classical references such as the ahkam tafsir verse, syarah muamalah hadith, muqaran fiqh, aqdiyah wa nawazil, decisions of international fatwa authorities. If the DSN fatwa is adopted into regulation, it becomes binding together between ulama and bank activists such as the government and the private sector. For this, Muawanah (2018) finds that the legal actions of directors representing a limited liability company in binding credit at Islamic banks by guaranteeing company assets can follow the legal basis of the results of the ulama fatwa deliberations represented by the Islamic ummah.

Here we want to understand the relevance of the provisions of sharia law with its application in the field, especially in Islamic banking in Indonesia, through a literature review of international publications. As researchers, 
we believe that not all Islamic Sharia principles and concepts have been implemented following existing regulations. This belief is strengthened by the conversion effect of banking in Indonesia. Basuki (2019) states that legal analysis on the conversion process of conventional banks to Islamic Banks impacts the adaptation of the way conventional banks operate when they face the adaptation of Islamic banks. Budiarti (2011) in his study of the effect of service quality and complaint handling on customer satisfaction and loyalty of Islamic Commercial Banks in Surabaya. Problems and possible complaints from customers are often encountered from public services provided by Islamic banks. We can ensure that this assumption will be answered through a review of various field studies. This means that there is no relevance between sharia law policies and regulations and the bank's application. The thing that makes us believe that there will be actions outside the way of sharia law is that the Islamic banks are used to conventional banks' workings, which are suddenly converted into Islamic sharia banks. To ensure our assumptions on both things, Islamic sharia law and regulations and applications by banking in the field (Arifin, 2012).

\section{Method}

This paper tried to survey the principles, significance, and handiness of Islamic monetary law in applying Islamic bank association structures in various countries. Islamic sharia law has become the wellspring of all laws in a couple of Islamic countries and various countries like Indonesia. Sharia law starts from the Islamic religion, which ought to be applied in various regions recollecting for the monetary system. The fact is believe it or not to improve the demonstration of Islamic exercises kaffah into all pieces of life by holding fast to the Koran, which is alone a plan to be applied into various structures fundamentally. Yet this monetary system has become a fundamental law in sweeping terms, an examination is at this point expected to find the importance, guidelines, and utilization of Islamic monetary law with field applications to see the good conditions and downsides of usage in the field. A start to finish data examination measure was endeavored, which included data coding, essential agreement, and evaluation that organized the disclosures with the discussion subject and chose the revelations' authenticity and steady quality (Sgier, 2012; Bazeley \& Jackson, 2013; Berg, 2001).

\section{Result}

According to Rodliah et al. (2017) Islamic bank governance rules have become an attribute that must be implemented to manage Islamic banking organizations in carrying out customer administration. In Islamic banking, which is known as sharia administration, the sharia standards can be improved. However, current Islamic financial practices have not met the essential standards of the sharia administration. Look at problems; the paper intends to look from the top down on the criticality of the sharia administration. Apart from that, it also investigates the convergence between Islamic administration and the idea of worldly rights for customers. This paper makes use of philosophical, juridical, and standard sense methodologies. As a result of this study, as a right, a privilege that customers need to obtain security guarantees for the implementation of sharia administration. Caution regarding this enormous guarantee of rights is expected to bring the Islamic financial industry to a high level of confidence, to gain public certainty. The implied belief is if clients have certainty that Islamic banking maintains Islamic standards in their activities to be mandated by Islamic standards.

The findings of Yazdan \& Mohammad Hossein (2012) are that this paper's motivation is to analyze the past short and long-term relationships between changes in Islamic financial events and monetary developments in Iran and Indonesia. It also examines Islamic financing methods and the responsibility of business banks to enforce fundamental Islamic finance law. The results show a substantial relationship between the turn of Islamic monetary events. The relationship gives the impression of a two-way relationship. This paper uses appropriate evidence to show that the work of Islamic bank financing on monetary execution in two countries is following the principles and concepts of Islamic financial governance.

Alamer et al. (2015) examined scientific understanding efforts that have been initiated over the last few decades to assess corporate social and religious (CSR) duties and responsibilities in the implementation of Islamic Bank (IB). In Islam, the IB business cycle can never be separated from the contemplation of public/community morals. The concepts and principles of IB for the general public can become a new element for Islamic banking to measure customers and society's effect. This article can finally prove the bank's new commitment to sharia duties to pave the way for additional exploration to show a deeper agreement between Islamic banks and the Islamic customer community. 
According to Prabowo \& Jamal (2017) Islamic banks have developed further by providing innovative services and administration, effectively increasing clients' numbers over time. In Murabaha, the bank plots as a dealer (ba'i) to buy imported goods and then exchange them with customers, customers (musytari) with business values identical to the price tag and bank productivity. Indonesia's main problem is that there are legal arrangements that are incompatible and not based on genuine shopper rights. Islamic banks that take advantage of wakalah invite customers to buy their products, but it is not wise to apply the idea to customers because MUI Fatwa No. 04/DSNMUI/IV/2000 has stipulated that the Murabahah contract offer is made after the merchandise belongs to the standard Islamic finance.

Reni (2013) studied the elements that affect the determination of Islamic banking customers' rights, is essential. He added that social transformation towards a sustainable society had been the motivation behind this research. To dissect and decide on the inward client component (disposition) and external/social variables (emotional standards) to determine the appropriate Islamic banking expectations, still takes more time. The main reasons are that there are many background variables, including understanding religious law, lack of information about Islam, lack of communication/lack of extensive publicity, lack of government support, and less enforcement of innovation compared to other banks.

Likewise, Aisyah (2018) findings regarding the quality of Islamic bank administration and its impact on customer fulfillment and loyalty in Indonesia were done. His study shows that the quality of Islamic bank administration in Indonesia impacts consumer loyalty and resilience. However, consumer loyalty will affect client loyalty. It was found that Islamic bank customers were still disappointed with the administration provided by Islamic banks. This study suggests techniques to improve customer assistance and assurance regarding the differentiation of Islamic financial frameworks must be adjusted to standard Islamic bank rules that have principles and concepts that customers want.

Qoyum et al. (2017) found 10 Islamic banks in Indonesia as exploration; then, 40 annual reports were completed through purposive examination. The exploratory findings show that the autonomous chief bank supervisor cannot provide the best oversight of the organization, which is affected by the absence of standardized service values. Meanwhile, the organization's size dramatically influences the bank organization's exposure because strict guidelines and customer insight are increasingly high. The findings of this study can be a significant contribution for supervisors to direct the management of the number of autonomous officials, their capabilities and capabilities, and Islamic Social Reporting as a tool to reveal their CSR.

Alam et al. (2019) said the sharia governance framework is a fundamental cycle in which Islamic banks filter, control, and direct their implementation. Their review reveals that Bangladesh's Sharia administrative framework is intentional and not administrative, and there is an undeniable SGF. This paper audits current practice, issues, legal and administrative matters using deductive methods and provides suggestions for improving SGF in Bangladesh. It appears that the Board of Directors (BOD) uses the Sharia Supervisory Board (SSB) in achieving their objectives and is responsible for Sharia practice in general as opposed to SSB. Bank of Bangladesh (BB) should issue a comprehensive Centralized SGF describing jobs, power, and elements. So that the people of Bangladesh can feel the services and concepts, and principles of Islamic banking.

Nugroho et al. (2018) assess Indonesia's reality that the source of capital for all Islamic banks is the assistant to Conventional Banks (other than Bank Muamalat). Bank Syariah Mandiri, the only Sharia Bank that fulfills capital ownership with the business category Bank-level III is more of an assistant to Bank Mandiri (a commercial bank). Likewise, commercial banks are becoming more potent in meeting the capital requirements for Islamic Bank affairs. This article intends to select a piece of capital and work benefits for business progress (financing) at Bank Syariah Mandiri. The procedure used is quantitative techniques using quantitative tools STATA variation 13. The backslide test results show that capital and profits have a considerable influence in growing Islamic banks' expansion of financing. Also, the terrible number of commitments is causing the public to lose confidence in Islamic banks. The choice rather than growing capital and public trust is the government's way of handling Islamic bank assistance for free.

As indicated by Mukhibad (2019) Islamic banks and their operational principles have credible operational contrasts, so it is more astute to quantify the presence of these two kinds of concurrences with notes with various devices. One proportion of elective execution is the Maqasid Syariah. Examinations have been composed to decide if banking administration, the Sharia Supervisory Board, and Company Ethics have added to the accomplishment of Maqasid Syariah. Our analytical test was run on the Islamic financial business in Indonesia with an adroit period from 2009-2017. The consequences of the examination, Sharia Maqasid have not been done by Islamic banks in Indonesia as per the assumptions for sharia. This reality is appeared by the nonappearance of any piece of the corporate association and SSB in guaranteeing that the Maqasid Syariah is satisfied. Great Corporate Governance 
influences benefits. Islamic Monetary makes a positive commitment towards Company Ethics, and immovably influences proficiency and Maqasid Syariah.

Next are the aftereffects of the examination by Nugroho et al. (2018) which express that the force of banks has a significant part in keeping up financial dissemination. Consequently, this division method is required because it expects to improve bank monetary security (decline in Non-Performing Loans-NPL/Non-Performing FinancingNPF). This examination is required to choose the impact of circulation on the possibility of Islamic banks proxied by NPF. The methodology utilized is a quantitative strategy with an alternate alongside test and a deliberate mechanical gathering of Stata rendition 13. From the consequences of quantitative information, it tends to be seen that the retail piece has a more noteworthy impact than the value decrease section, to be specific $92.61 \%$ and $56.05 \%$. Sharia banks ought to have business needs in the retail area, particularly organizations in the microfinance division while as yet advancing the possibility of financing through express financing moves.

Finally, Abduh \& Azmi Omar (2012) the inspiration driving this paper is to dissect the short and long-term associations between new developments in Islamic economic and money-related progress in Indonesia. The results show the fundamental relationship in the short term and since the previous period between Islamic Islamic bank money related to unexpected developments and events of monetary turnover. The connection, however, is not Schumpeter's stop - driving or Robinson's profit - following. This gives off the impression of a two-way relationship. This paper uses objective evidence to show the portion of Islamic bank financing to disbursement of money related to a country. For the author's most astonishing perspective, the on-the-job assessment of Islamic monetary developments towards improving finance is limited, particularly concerning banks in Indonesia.

\section{Discussion}

In this part of the discussion, we will describe our study's findings to understand the suitability of the principles and concepts of Islamic banking law with the application of these rules by Islamic banks themselves. As mentioned earlier, the data in this study report is based on a collection of literature and the results of a review of ten paperboard publications that write about Islamic banking practice in several countries. Here we can report that, in general, our findings are that most experts report that the Islamic banks in several countries have implemented the function of the sharia law as the operational basis for Islamic banks, namely with a best practice system as aspired by sharia Islamic banks. This is under Abdul-Rahman \& Nor (2017) work, which raised awareness and willingness towards Islamic banking among Muslims. Indeed, we admit that there is also a small percentage of reports from experts who report that there are still legal banks to apply the standard of Islamic banking practices because of the regulations and are still adapting from conventional wisdom to Islamic banks.

The report on the results of this study is beneficial because the conditions and context of each country's regulatory system are different so that it also has an impact on the system and approach of each Islamic bank. With these findings, each bank will be easy to see the case cases experienced by Islamic banks that have just been convicted from conventional banks. The weakness of this finding is that this data is the result of a review of previous studies. Where this study method is still in one design model, the namely qualitative design is not enough. For the data to be more sticky, it is necessary to combine two qualitative and quantitative research designs. Sudarsono (2017), with an analysis of the Effect of Financial Performance on the Profitability of Islamic Banks in Indonesia, has supported this finding.

\section{Conclusion}

Finally, arriving at a summary of the discussion of the findings of this study, which aims to understand the suitability between the concepts and principles of Islamic economics applied by the managers of Islamic banks and the data source is the result of a review of international publications. In general, Islamic Islamic banks' management has carried out the Islamic concept with the guidelines of Islamic principles. It is just that Kendela, according to analysis data, shows that a small number of people still need an adaptation period in the management of Islamic banking in each country. Another reason is that they are still under guidance from banking regulations that are in line with expectations. Thus, this study's results will be useful for observers and executing bodies of Islamic Islamic banking in the world. 


\section{Acknowledgments}

We authors would like thank to all authorship supports from my colleagues and university supervisors with useful feedback during the writing of the project entitled "the principles, relevance of Islamic law implementation in syariah bank in Indonesia".

\section{References}

Abdad, M. Z. (2019). Signifikansi fatwa dsn mui terhadap perkembangan ekonomi syariah di indonesia. istinbath, 18(2).

Abdul-Rahman, A., \& Nor, S. M. (2017). Challenges of profit-and-loss sharing financing in Malaysian Islamic banking. Geografia-Malaysian Journal of Society and Space, 12(2).

Abu-Tapanjeh, A. M. (2009). Corporate governance from the Islamic perspective: A comparative analysis with OECD principles. Critical Perspectives on accounting, 20(5), 556-567. https://doi.org/10.1016/j.cpa.2007.12.004

Aisyah, M. (2018). Islamic bank service quality and its impact on Indonesian customers' satisfaction and loyalty. AlIqtishad Journal of Islamic Economics, 10(2), 367-388.

Alam, M. K., Ab Rahman, S., Mustafa, H., Shah, S. M., \& Hossain, M. S. (2019). Shariah governance framework of Islamic banks in Bangladesh: Practices, problems and recommendations. Asian Economic and Financial Review, 9(1), 118.

Alamer, A. R. A., Salamon, H. B., Qureshi, M. I., \& Rasli, A. M. (2015). CSR's measuring corporate social responsibility practice in Islamic banking: A review. International Journal of Economics and Financial Issues, 5(1S).

Amin, M. R. (2017). Solusi hukum Islam (makharij fiqhiyyah) sebagai pendorong arus baru ekonomi syariah di Indonesia: kontribusi fatwa DSN-MUI dalam Peraturan Perundang-Undangan RI.

Antonio, M. S. I. (2001). Bank Syariah: dari teori ke praktik. Gema Insani.

Arfaizar, J. (2020). Increase in revenue of tokopedia community yogyakarta from the perspective of islamic business ethics. Indonesian Journal of Interdisciplinary Islamic Studies, 3(2), 38-50.

Auda, J. (2008). Maqasid al-Shariah as philosophy of Islamic law: a systems approach. International Institute of Islamic Thought (IIIT).

Azhar, A. (2020). The Need for Collective Ijtihad between the Fuqaha and Experts in Health Science and Modern Medicine: A Review. International Journal of Psychosocial Rehabilitation, 24(2).

Basuki, A. Y. (2019). Analisis Yuridis Terhadap Konversi Bank Konvesional Menjadi Bank Syariah (Studi pada PT. Bank Aceh Syariah Kantor Utama Banda Aceh).

Bazeley, P. (2013). Qualitative data analysis: Practical strategies. Sage.

Berg, B. R. U. C. E. (2001). Qualitative research methods for the social sciences.

Budiarti, A. (2011). Pengaruh Kualitas Layanan Dan Penanganan Keluhan Terhadap Kepuasan Dan Loyalitas Nasabah Bank Umum Syariah Di Surabaya. Ekuitas (Jurnal Ekonomi Dan Keuangan), 15(2), 210-231.

Deti, S. (2015). Kesiapan Perbankan Syariah Indonesia Berkompetisi di Era MEA Dalam Proceeding of 1st International Conference on ASEAN Economic Community in Borneo Region. Kerjasama Dengan Institut Agama Islam (IAI) Sultan Muhammad Syafiuddin Sambas Kalimantan Barat dengan Kalimetro Intelegensia.

Eid, W. K., \& Asutay, M. (2019). Mapping the risks and risk management practices in Islamic banking. John Wiley $\&$ Sons.

El-Galfy, A., \& Khiyar, K. A. (2012). Islamic banking and economic growth: A review. Journal of Applied Business Research (JABR), 28(5), 943-956.

Fauzia, I. Y. (2014). Prinsip Dasar Ekonomi Islam Perspektif Maqashid Al-Syariah. Kencana.

Hardini, I. (2007). Kamus perbankan syariah: dilengkapi penjelasan singkat dan perbandingan dengan bank konvensional. Marja.

Hessini, L. (2007). Abortion and Islam: policies and practice in the Middle East and North Africa. Reproductive health matters, 15(29), 75-84. https://doi.org/10.1016/S0968-8080(06)29279-6

Majid, M. Z. A. (2012). Maqasid Al-Syariah. LlUm Press.

Maradita, A. (2014). Karakteristik Good Corporate Governance Pada Bank Syariah dan Bank Konvensional. Yuridika, 29(2).

Muawanah, M. (2018). Perbuatan Hukum Direksi Mewakili Perseroan Terbatas Dalam Pengikatan Kredit di Bank Dengan Penjaminan Aset Perusahaan. Repertorium: Jurnal Ilmiah Hukum Kenotariatan, 4(1). 
Mukhibad, H. (2019). The Role Of Sharia Supervisory Boards in Meeting Maqasid Syariah-Study on Islamic Banks in Indonesia. European Journal of Islamic Finance, 13, 1-10.

Nugroho, L., Hidayah, N., \& Badawi, A. (2018). The Islamic Banking, Asset Quality:"Does Financing Segmentation Matters"(Indonesia Evidence). Mediterranean Journal of Social Sciences, 9(5), 221.

Olson, D., \& Zoubi, T. A. (2008). Using accounting ratios to distinguish between Islamic and conventional banks in the GCC region. The International Journal of Accounting,43(1), 45-65. https://doi.org/10.1016/j.intacc.2008.01.003

Othman, N. (2006, July). Muslim women and the challenge of Islamic fundamentalism/extremism: An overview of Southeast Asian Muslim women's struggle for human rights and gender equality. In Women's Studies International Forum (Vol. 29, No. 4, pp. 339-353). Pergamon. https://doi.org/10.1016/j.wsif.2006.05.008

Prabowo, B. A., \& Jamal, J. B. (2017). Concept And Application Of Akad Wakalah In Murabaha Financing In Islamic Banking (A Comparative Study Between Indonesia And Malaysia). Diponegoro Law Review, 2(1), 1-14.

Putra, P., Liriwati, F. Y., Tahrim, T., Syafrudin, S., \& Aslan, A. (2020). The students learning from home experiences during Covid-19 school closures policy in Indonesia. Jurnal Iqra': Kajian Ilmu Pendidikan, 5(2), 3042.

Putrayasa, I. B. (2017). The semantic study of languages politics. International journal of linguistics, literature and culture, 3(2), 7-13.

Qoyum, A., Mutmainah, L., Setyono, J., \& Qizam, I. (2017). The impact of good corporate governance, company size nn corporate social responsibility disclosure: Case study of Islamic banking in Indonesia. Iqtishadia, 10(1), 103-159.

Reni, A. (2013). The factors influencing customer selection Islamic banking. Social Transformation toward Sustainable Society, 75.

Rodliah, N., Setyowati, R. A., \& Abubakar, L. (2017). Sharia Governance On Islamic Banking: Spiritual Rights Perspective On Consumer Protection In Indonesia. Diponogoro Law Review, 2(1), $227-244$.

Sgier, L. (2012). Qualitative data analysis. An Initiat. Gebert Ruf Stift, 19, 19-21.

Shibani, O., \& De Fuentes, C. (2017). Differences and similaritites between corporate governance principles in Islamic banks and Conventional banks. Research in International Business and Finance, 42, 1005-1010. https://doi.org/10.1016/j.ribaf.2017.07.036

Sudarsono, H. (2017). Analisis Pengaruh Kinerja Keuangan terhadap Profitabilitas Bank Syariah di Indonesia. Economica: Jurnal Ekonomi Islam, 8(2), 175-203.

Supriyono, S. E., \& Khalifaturofi'ah, S. O. (2021). Pelatihan perbankan syariah bagi guru-guru SMK. Jurnal Terapan Abdimas, 6(1), 49-54.

Tripuspitorini, F. A., \& Setiawan, S. (2020). Pengaruh faktor makroekonomi terhadap pertumbuhan dana pihak ketiga pada bank umum syariah di Indonesia. Jurnal Riset Akuntansi dan Keuangan, 8(1), 121-132.

Utama, A. S. (2018). Sejarah dan Perkembangan Regulasi Mengenai Perbankan Syariah dalam Sistem Hukum Nasional di Indonesia. Jurnal Wawasan Yuridika, 2(2), 187-200.

Wahid, S. H. (2016). Pola Transformasi Fatwa Ekonomi Syariah DSN-MUI Dalam Peraturan Perundang-Undangan Di Indonesia. Jurnal Ahkam, 4(2), 171-198.

Yazdan, G. F., \& Mohammad Hossein, S. S. (2012). Analysis of Islamic Bank's Financing and Economic Growth: Case Study Iran and Indonesia. Journal of Economic Cooperation \& Development, 33(4).

Yudhira, A. (2021). Analisis perkembangan financial technology (fintech) syariah pada masa pandemi covid-19 di Indonesia. value, 2(1), 13-28.

Zainul Arifin, M. B. A. (2012). Dasar-dasar manajemen bank syariah. Pustaka Alvabet.

Zohdi, A. (2017). Islamic scientific epistemology in Al-Jabiri perspective. International journal of linguistics, literature and culture, 3(5), 26-35. 